\title{
Ohjauksen mahdollisuuksien tajua
}

\section{Onnismaa J., Pasanen H. , Spangar T. (toim. 2000) Ohjaus ammat- tina ja tieteenalana 1 , Ohjauksen lähestymis- tavat ja ohjaustutki- mus sekä Ohjaus am- mattina ja tieteenala- na 2, Ohjauksen toi- mintakentät PS-KUSTANNUS}

\section{Ohjaus- ja neuvontatyö}

on tullut entistä merkittävämmäksi yhteiskunnallisen ja yhteisöllisen elämämme muuttuessa epävarmemmaksi ja ennakoimattomammaksi. Ohjaus toimii minuuden koostamisen paikkana ja suuntimisen apuna näinä aikoina, jolloin joudumme rakentamaan itseämme aina uudelleen ja etsimään opiskelun, ammatillisen uran ja elämänkentän suuntia. Muuttuvat ja laajenevat toimintaympäristöt edellyttävät ohjaus- ja neuvontatyöltä ammattikäytäntöjen kehittämistä, eri ammattiryhmien yhteistyötä ja tutkimuksen ja ammatillisen toiminnan kumppanuutta sekä omien mahdollisuuksien näkemyksellistä tajua ja tähän pohjautuvaa käytäntöjen kehittämistä.

\section{Tervetulleena}

johdatuksena ohjauksen mahdollisuuksiin toimii kaksiosainen teossarja Ohjaus ammattina ja tieteen alana 1-2. Teoksista ensimmäinen käsittelee ohjauksen lähestymistapoja, vaikutusvaltaisimpia suuntauksia ja menetelmiä sekä ohjauksen tutkimusta. Toinen osa esittelee perinteisiä ja uusia alueita, joilla toimitaan ohjauksellisilla työtavoilla. Kirjoittajat, joita on kaiken kaikkiaan kolmekymmentäviisi, ovat alueensa asiantuntijoita. Jo kirjoittajien runsaus saa aikaan sen, että teoksista syntyy moniääninen ja kerroksittainen todellisuus.

\section{Teoksista ensimmäinen} esittelee ohjaussuuntausten vaikutusvaltaisimpia suuntia. Vance Peavy jäsentää ammatinvalinnan ja urasuunnittelun ohjausta postmodernina aikana esittelemällä narratiivista, toiminnallista ja sosiodynaamista ohjausta. Luotu perusta laajentaa ohjauksen tieteellistä perustaa psykologiasta sosiologiseen mielikuvitukseen sekä kulttuuriseen näkökulmaan. Tämä teoksen ensimmäinen artikkeli luo kehittyvien ideoiden maiseman, jonka kanssa monet muut teoksen artikkelit käyvät intertekstuaalista keskustelua. Voimavara- ja ratkaisukeskeinen ote sekä NLP ja inhimillisen taidon mallittaminen yhtyvät keskusteluun . Omaelämänkerrallinen ote Merja Korhosen jäsentämänä liittyy narratiivisuuden teemaan. Annaraija Nummenmaan ja Päivi-Katriina Korhosen esittelemä sukupuolitietoinen ohjaus rakentuu elämänkulun näkökulmalle ja konstruktivistisen ohjauksen perustalle. Samoin psykopedagoginen ryhmäohjaus muutoksen mahdollisuuden maisemana pääsee esille Annaraija Nummenmaan, Ritva Ruposen ja Merja Koivulehdon artikkelissa, jossa esitellään myös ohjauksellista toteutusta käyttäen esimerkki- nä Löytöretki omaan osaamiseen - ryhmäohjausmallia. Kirsti-Liisa Kuusinen esittelee kognitiivista psykoterapiaa, yhtä psykologisen ohjauksen valtavirroista liittäen suuntauksen viimeaikaisen kehityksen myös konstruktivistisiin painotuksiin. Raimo Lahti jäsentää psykoanalyyttista suuntausta esittäen, että psykoanalyyttisen suuntauksen lähtökohdat ovat paljolti sopusoinnussa empowerment käsitteen ja elämän sosiaalisen muotoamisen kanssa: Yksilöä autetaan löytämään sisäiset voimavaransa. Ohjaussuhteen kehittymisellä on tässä merkittävä tehtävänsä.

\section{Pentti Sinisalo jäsentää}

ohjauksen ja neuvonnan tutkimusta Suomessa käsittelevässä artikkelissaan tutkimuksen vaiheita, painopisteitä ja katvealueita. Painopisteet väitöskirjojen perusteella mitoitettuna ovat olleet uravalinta ja urakehitys sekä ohjausprosessiin kohdistuva tutkimus. Tutkimukselliseen katvealueeseen jäävät sukupuolisensitiivinen ja monikulttuurinen ohjaus sekä ohjaus moniammatillisena toimintana. Muutamat tuoreet väitöskirjat pääsevät ensimmäinen teoksen lopussa näyttämölle: Helena Kasurinen tiivistää suomalaisten ja venäläisten nuorten tulevaisuus-orientaatiosta tekemänsä väitöskirjan tuloksia. Sanna Vehviläinen esittelee ohjausvuorovaikutuksen tutkimusta keskusteluanalyysin keinoin. Katri Komulainen jäsentää kertomuksia, elämänmetaforia ja ydinretoriikkoja ohjauksen välineinä. 
Teossarjan toisessa osassa

ohjauksen toimintakentiksi

jäsennetään ohjaus ja urasuunnittelu, ohjaus oppimisen tukena, ohjaus työelämässä ja ohjauksellisuus kuntoutuksessa ja perhetyössä. Tässä toisessa osassa vuorottelevat näkemykselliset toimintakentän analyysit ja käytännöllisemmät jonkin kentän osan katsaukset. Timo Spangar käsittelee ammatinvalinnanohjausta neuvotteluina ja kehkeytyvänä prosessina. Jukka Vuorinen jäsentää koulujen opintoohjausta empowermentin näkökulmasta, mikä tarkoittaa oppimisen ja elämän aktiivisen kehittämisen yhdessä vanhempien ja opettajien kanssa. Heikki Pasanen analysoi oppimisen ohjausta ammatillisessa aikuiskoulutuksessa eritellen kriittisesti mm. itseohjautuvuuden trendiä. Pauli Juuti avaa ohjauksen mahdollisuuksia organisaatioiden johtamisessa etsimällä tapoja sovittaa ohjauksellisia elementtejä postmoderneihin verkosto-organisaatioihin. Seppo Lahikainen avaa ohjanta- ja neuvontatyön näköaloja kuntoutuksessa pohtimalla, mitä ajan, huomion ja kunnioituksen antaminen todella merkitsevät.

\section{Käytännönläheisempiin}

katsauksiin kuuluvat mm. työttömyyttä ja ohjausta, urasuunnitteluohjausta internetissä, ohjauksen strategisia kysymyksiä koulutusorganisaatioissa, työssäoppimista ja sen ohjaamista sekä HOPS:ien ohjaamista. Marjatta Lairio ja Sauli Puukari esittelevät Leonardo-projektiin perustuen Suomen yliopistojen ohjausja neuvontapalvelujen tilannetta. Riitta Metsänen jäsentää maahanmuuttajien ohjauksesta ja monikulttuurisesta työyhteisöstä keräämiensä kokemusten kautta monikulttuurista ohjausta. Työelämän ohjausta lähestytään myös käsittelemällä henkilöstötilinpäätöstä sekä ikääntyviä työntekijöitä.

\section{Teossarja päättyy}

ohjauksen muuttuneiden ehtojen analyysiin. Näin alussa luotu postmoderni jännite saa lopputulemansa. Jussi Onnismaa pohtii ohjaustyön etiikkaa lähtien siitä, että epävarmuuden myötä eettiset kysymykset nousevat uudella tavalla ammattikäytännön ytimeen. Pekka Kosonen pohtii myöhäismodernin ajan tuomia elämäntaidollisia haasteita sekä ohjauksen asiantuntijuuden kehittämissuuntia päätyen $\mathrm{mm}$. siihen, että ihmisten persoonallisuuteen ja elämäntaitoihin liittyvien toimien tulisi ennen kaikkea huolehtia luottamuksen ja dialogisen tilan syntymisestä.

\section{Kirjan toimittajat}

toteavat, että teoksista voi olla vaikea yhdellä katsauksella muodostaa ristiriidatonta kokonaisuutta. Ristiriidattoman kokonaisuuden yrittäminen olisikin ollut väkivaltaa ohjauksen todellisuudelle ja ohjauksen toimintaympäristöjen monimuotoisuudelle. Teokset ovat osaltaan edistämässä ohjauksen ammattilaisten keskinäistä vuoropuhelua. $\mathrm{Ne}$ toimivat tarpeellisina käsikirjoina ohjausalan aloitteleville, pidemmälle ehtineille ja ikuisillekin opiskelijoille.

Marjatta VanhalakkaRuoho

\section{Kirjallisuutta kiinnostuneille}

- OSMO KIVINEN \& PEKKA RISTELÄ (2001) Totuus, kieli ja käytäntö. Pragmatistisia näkökulmia toimintaan ja osaamiseen. WSOY (196 s.)

- VILMA HÄNNINEN, JUKKA PARTANEN \& OILI-HELENA YLIJOKI (2001) Sosiaalipsykologian suunnannäyttäjiä. Vastapaino (406 s.)

- TUOMO ALASOINI (2000) Suomalaisen työelämän kehittämiskokeilu 1996-99 - kokemuksia, näkemyksiä ja tuloksia Kansallisesta työelämän kehittämisohjelmasta. (136 s.) Työministeriö.

- MATTII VARTIAINEN, SAARA PIRSKANEN, ANNA PALVA \& TIINA SIMULA (2000) Tiimiprojektien vaikutukset ja onnistuminen. (180 s.). Työministeriö

- PENTTI YRJÖLÄ, JAAKKO ANSAHARJU, PETRI HALTIA, RAIMO JAAKKOLA, ANU JÄRVINEN, TIM LAMMINRANTA \& MATTI TAALAS (2000) Näyttötutkintojärjestelmän kokonaisarviointi. Arviointi 12, Opetushallitus. (290 s.) 